\title{
ANALISIS PERLAKUAN AKUNTANSI ASET TETAP PADA DINAS PEKERJAAN UMUM (PU) PROVINSI SULAWESI UTARA
}

\author{
Akhyar Tipan ${ }^{1}$ \\ David Paul Elia Saerang 2 \\ Robert Lambey ${ }^{3}$ \\ Fakultas Ekonomi dan Bisnis Jurusan Akuntansi \\ Universitas Sam Ratulangi Manado \\ Email: achyar_tipan@yahoo.com
}

\begin{abstract}
Fixed assets have a very important role for the smooth operation of government services to maximize the activity takes appropriate policy in the management of fixed assets. Department of Public Works (PU) North Sulawesi is an institution that supports the affairs of the District / Town in the field of public works who carry out tasks in the District / City of North Sulawesi. Service vehicles, equipment and machinery, land, buildings, roads, and the fixed assets owned by the Department of Public Works North Sulawesi and very important in supporting the activities of government services. This study aimed to analyze the accounting treatment for fixed assets at the Department of Public Works North Sulawesi what was in accordance with Regulation 71 Year 2010 Statement of Government Accounting Standards (PSAP) No. 07 of the fixed assets. The method used is descriptive analysis method with a way to understand the reality and compare it with the theory that the researchers studied so it can be concluded. In the study the accounting treatment of fixed assets has been good. In practice, in the way of acquisition of fixed assets Public Works Department to make a purchase in cash, Department of Public Works has not shrunk its fixed assets where it is not in accordance with the Governmental Accounting Standards applicable, Department of Public Works to stop the fixed assets that are not used by way of eliminating it from the balance sheet and transferred to the post other fixed assets, as well as in the presentation and disclosure, the Department of Public Works has revealed the fixed assets in accordance with accounting standards applicable rule.
\end{abstract}

Keywords $\quad$ : Fixed Assets, PSAP N0.07

\section{PENDAHULUAN}

Salah satu kebijakan pemerintah Republik Indonesia yang memiliki pengaruh starategis dari segi hukum, politik, dan ekonomi yang dideklarasikan pada tahun 1999 adalah Otonomi Daerah yang diatur dalam Undang-Undang Nomor 22 Tahun 1999 tentang Pemerintahan Daerah yang kemudian direvisi menjadi Undang-Undang Nomor 32 Tahun 2004 Tentang Pemerintahan Daerah.

Otonomi daerah adalah hak, wewenang, dan kewajiban daerah otonom untuk mengatur dan mengurus sendiri urusan pemerintahan dan kepentingan masyarakat setempat sesuai dengan peraturan perundang-undangan (UU RI Nomor 32 Tahun 2014 Pasal 1 ayat 5).

Dengan diberlakukannya Otonomi Daerah maka, setiap provinsi, kabupaten, dan kota yang ada di Indonesia diharuskan untuk melakukan pengelolaan dan pertanggungjawaban keuangannya sendiri, untuk itu sebagai pedoman didalam melaksanakan pengelolaan dan pertanggungjawaban keuangan daerah maka dikeluarkanlah Peraturan Pemerintah Nomor 58 Tahun 2005 Tentang Pengelolaan Keuangan Daerah.

Dalam sistem Akuntansi Pemerintah Daerah terdapat 2 subsistem, yaitu Satuan Kerja Pengelola Keuangan Daerah (SKPKD) dan Satuan Kerja Perangkat Daerah (SKPD). Laporan keuangan SKPD merupakan sumber untuk menyusun Laporan Keuangan SKPKD, oleh karena itu setiap SKPD harus menyusun Laporan keuangan sebaik mungkin

Dalam Sistem Akuntansi Pemerintahan ditetapkan entitas pelaporan dan entitas akuntansi yang menyelenggarakan sistem akuntansi pemerintahan daerah. Sistem akuntansi daerah secara garis besar terdiri atas empat prosedur akuntansi, yaitu: prosedur akuntansi penerimaan kas, pengeluaran kas, selain kas, dan aset. 
Aset adalah sumber daya ekonomi yang dikuasai dan/atau dimiliki oleh pemerintah sebagai akibat dari peristiwa masa lalu dan dari mana manfaat ekonomi dan/atau sosial di mana masa depan diharapkan dapat diperoleh, baik oleh pemerintah,masyarakat, serta dapat diukur dalam satuan uang, termasuk sumber daya nonkeuangan yang diperlukan untuk penyediaan jasa bagi masyarakat umum dan sumber-sumber daya yang dipelihara karena alasan sejarah dan budaya . Aset tetap adalah aset berwujud yang mempunyai masa manfaat lebih dari 12 (dua belas) bulan untuk digunakan, atau dimaksudkan untuk digunakan, dalam kegiatan pemerintah atau dimanfaatkan oleh masyrakat umum(Standar Akuntansi Pemerintahan Pernyataan No. 07).

Dinas Pekerjaan Umum (PU) Provinsi Sulawesi Utara merupakan Dinas yang mempunyai tugas pokok untuk melaksanakan urusan pemerintahan daerah di bidang pekerjaan umum, tugas dekonsentrasi dan tugas pembantuan serta kewenangan lintas Kabupaten/Kota Provinsi Sulawesi Utara berdasarkan Peraturan Daerah Sulawesi Utara Nomor 4 Tahun 2006, maka Dinas Pekerjaan Umum (PU) provinsi Sulawesi Utara juga harus membuat pertanggungjawaban atas kewenangan yang dilaksanakannya sesuai dengan Peraturan Pemerintah Nomor 71 Tahun 2010 Tentang Standar Akuntansi Pemerintahan.

Berdasarkan latar belakang yang telah diuraikan oleh penulis di atas, maka rumusan masalah dalam penelitian ini adalah mengenai perlakuan akuntansi atas Aset Tetap pada Dinas Pekerjaan Umum Provinsi Sulawesi Utara sesuai PP No.71 Tahun 2010.

\section{TINJAUAN PUSTAKA}

\section{Definisi Akuntansi}

Akuntansi sangat diperlukan oleh suatu perusahaan, karena dengan akuntansi kegiatankegiatan yang mengubah posisi keuangan perusahaan diproses menjadi suatu informasi yang berguna bagi pengguna laporan keuangan.

Soemarso S.R (2010:3), mengemukakan pengertian akuntansi menurut American Institute Of Certified Public Accountant (AICPA) sebagai berikut, "Akuntansi adalah proses mengidentifikasikan, mengukur, dan melaporkan informasi ekonomi, untuk memungkinkan adanya penilaian dan keputusan yang jelas dan tegas bagi mereka yang menggunakan informasi tersebut".

Suwardjono (2013:4), mengatakan kata akuntansi berasal dari kata bahasa Inggris to account yang berarti memperhitungkan atau mempertangungjawabkan. Kata akuntansi sebenarnya diserap dari kata accountancy yang berarti hal-hal yang bersangkutan dengan accountant (akuntan) atau bersangkutan dengan hal-hal yang dikerjakan oleh akuntan dalam menjalankan profesinya.

Ismail (2010:2), mengatakan akuntansi adalah seni dalam mencatat, menggolongkan dan mengikhtisarkan semua transaksi-transaksi yang terkait dengan keuangan yang telah terjadi dengan suatu cara yang bermakna dan dalam satuan uang.

\section{Definisi Akuntansi Pemerintahan}

Pada hakekatnya akuntansi pemerintahan adalah aplikasi akuntansi di bidang keuangan Negara (public finance), khususnya pada tahapan pelaksanaan anggaran (budget execution), termasuk segala pengaruh yang ditimbulkannya, baik yang bersifat seketika maupun yang lebih permanen pada semua tingkatan dan unit pemerintahan. (Kustadi Arinta) Adapun beberapa definisi mengenai akuntansi pemerintahan yang dikemukakan oleh beberapa para ahli yang diantaranya : Revrisond Baswir (2009:7), Akuntansi Pemerintahan (termasuk akuntansi untuk lembaga non profit pada umumnya) merupakan bidang akuntansi yang berkaitan dengan lembaga pemerintahan dan lembagalembaga yang bertujuan untuk tidak mencari laba. Walaupun lembaga pemerintah senantiasa berukuran besar, namun sebagaimana dalam perusahaan ia tergolong sebagai lembaga mikro.

Bachtiar Arif dkk (2010:3) mendefinisikan akuntansi pemerintahan sebagai suatu aktivitas pemberian jasa untuk menyediakan informasi keuangan pemerintah berdasarkan proses pencatatan, pengklaifikasian, pengikhtisaran suatu transaksi keuangan pemerintah serta penafsiran atas informasi keuangan tersebut.

Abdul Halim (2010:143) menyebutkan bahwa Akuntansi Pemerintahan adalah sebuah kegiatan jasa dalam rangka menyediakan informasi kuantitatif terutama yang bersifat keuangan dari entitas pemerintah guna pengambilan keputusan ekonomi yang nalar dari pihak-pihak yang berkepentingan atas berbagai alternatif arah tindakan. 
Nordiawan, Putra dan Rahmawati (2012:4) menjelaskan akuntansi pemerintahan mengkhususkan dalam pencatatan dan pelaporan transaksi-transaksi yang terjadi di badan pemerintah.

\section{Perbedaan Akuntansi Pemerintahan dan Akuntansi Komersial}

\begin{tabular}{|c|c|}
\hline Akuntansi Pemerintahan & Akuntansi Komersial \\
\hline $\begin{array}{l}\text { 1. Tujuannya adalah peningkatan } \\
\text { pelayanan dan kesejahteraan } \\
\text { masyarakat }\end{array}$ & $\begin{array}{l}\text { 1. Tujuannya adalah laba atau } \\
\text { keuntungan. }\end{array}$ \\
\hline $\begin{array}{l}\text { 2. Terdapat akuntansi untuk anggaran } \\
\text { (Budgetary Accounting) }\end{array}$ & 2. Tidak mengenal akuntansi anggaran. \\
\hline $\begin{array}{l}\text { 3. Mendahulukan aturan daripada } \\
\text { substansi kejadian. }\end{array}$ & 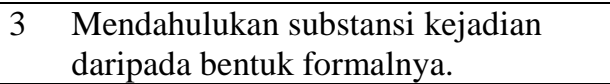 \\
\hline $\begin{array}{l}\text { Tidak mengenal modal pemilik, } \\
\text { ekuitas dana adalah merupakan selisih } \\
\text { antara asset dan hutang, yang } \\
\text { fungsinya hanya sebagai } \\
\text { penyeimbang. }\end{array}$ & $\begin{array}{l}\text { 4. Mengenal adanya modal pemilik, dan } \\
\text { setiap perubahannya mencerminkan } \\
\text { perubahan kekayaan pemiliknya. }\end{array}$ \\
\hline $\begin{array}{l}\text { 5. Ekuitas dana tidak dapat dibagikan } \\
\text { kepada pemiliknya. }\end{array}$ & $\begin{array}{l}5 \text { Modal pemilik dapat diambil sewaktu- } \\
\text { waktu oleh pemiliknya }\end{array}$ \\
\hline
\end{tabular}

(Sumber : BPKP 2002:41)

Meskipun memiliki perbedaan, pada dasarnya fungsi akuntansi dalam bidang apapun adalah sama yaitu menyajikan informasi bagi berbagai pihak tentang kejadian-kejadian ekonomi sebagai dasar pengambilan keputusan..

\section{Karakteristik Akuntansi Pemerintahan}

Akuntansi Pemerintahan memiliki karakteristik tersendiri jika dibandingkan dengan akuntansi bisnis. Berdasarkan tujuan pemerintah diatas, Bachtiar Arif, Muclis, Iskandar (2010:7) menyebutkan beberapa karakteristik akuntansi pemerintahan yaitu sebagai berikut:

1. Pemerintah tidak berorientasi pada laba sehingga dalam akuntansi pemerintah tidak ada laporan laba (income statement) dan treatment akuntansi yang berkaitan dengannya.

2. Pemerintah membukukan anggaran ketika anggaran tersebut dibukukan.

3. Dalam akuntansi pemerintahan dimungkinkan mempergunakan lebih dari satu jenis dana.

4. Akuntansi pemerintahan akan membukukan pengeluaran modal.

5. Akuntansi pemerintahan bersifat kaku karena sangat bergantung pada peraturan perundangundangan.

6. Akuntansi pemerintahan tidak mengenal perkiraan modal dan laba yang ditahan dalam neraca.

\section{Definisi, Klasifikasi dan Pengakuan Aset Tetap}

Aset Tetap merupakan salah satu elemen dari aset pada neraca yang digunakan dalam laporan keuangan suatu SKPD. Pada umumnya setiap Satuan Kerja Perangkat Daerah (SKPD) memiliki aset tetap untuk menunjang kegiatan yang dilakukan. Definisi aset tetap menurut Standar Akuntansi Pemerintahan (PP No.71 tahun 2010 pernyataan No. 07) : Aset Tetap adalah aset berwujud yang mempunyai masa manfaat lebih dari 12 (dua belas) bulan untuk digunakan dalam kegiatan pemerintah atau dimanfaatkan oleh masyarakat umum. Berikut adalah Klasifikasi Aset Tetap dalam pemerintahan:

1. Tanah

2. Peralatan dan Mesin

3. Gedung dan Bangunan

4. Jalan, Irigasi dan Jaringan

5. Aset Tetap Lainnya

6. Konstruksi Dlam Pengerjaan

Sesuai dengan klasifikasi Aset Tetap, suatu aset dapat diakui sebagai aset tetap apabila berwujud dan memenuhi kriteria :

1. Mempunyai masa manfaat lebih dari 12 (dua belas) bulan;

2. Biaya perolehan aset dapat diukur secara andal; 
3. Tidak dimaksudkan untuk dijual dalam operasi normal entitas;

4. Diperoleh/dibangun dengan maksud untuk digunakan.

Pemerintah mengakui suatu aset tetap apabila aset tetap tersebut telah diterima atau diserahkan hak kepemilikannya, dan atau pada saat penguasaannya berpindah. Oleh karena itu, apabila belum ada bukti bahwa suatu aset dimiliki atau dikuasai oleh suatu entitas maka aset tetap tersebut belum dapat dicantumkan di neraca. Prinsip pengakuan aset tetap pada saat aset tetap ini dimiliki atau dikuasai berlaku untuk seluruh jenis aset tetap, baik yang diperoleh secara individual atau gabungan, maupun yang diperoleh melalui pembelian, pembangunan swakelola, pertukaran, rampasan, atau dari hibah.

Perolehan aset tetap melalui pembelian atau pembangunan pada umumnya didahului dengan pengakuan belanja modal yang akan mengurangi Kas Umum Negara/Daerah

\section{Penelitian Terdahulu}

Andriyani Lysa 2008, dengan penelitian berjudul “Analisis Perlakuan Akuntansi Aset Daerah Dalam Penyusunan Neraca Pada Pemerintah Kabupaten Jember. Penelitian dilakukan dengan tujuan Menganalisis penerapan Akuntansi Aset Tetap pada Pemerintah Kota Tannjungpinang Sesuai SAP yang berlaku. Hasil penelitian menunjukkan bahwa, Akuntansi Aset Tetap pada Pemerintah Kota Tanjungpinang belum sesuai SAP yang berlaku. Terdapat persamaan dalam penelitian ini yaitu meneliti tentang Menganalisis Perlakuan Akuntansi Aset Tetap sesuai SAP yang berlaku. Sedangkan perbedaanya adalah Peneliti menggunakan sesuai SAP yang berlaku sekarang.

Tri Septiana (2011), Analisis Akuntansi Aset Tetap Pada Dinas Tenaga Kerja dan Transmigrasi Kabupaten Bungo Berdasarkan Standar Akuntansi Pemerintahan (Peraturan Pemerintah Nomor 24 Tahun 2005). Penelitian dilakukan dengan tujuan Untuk menganalisis Akuntansi Aset Tetap pada Dinas Tenaga Kerja dan Transmigrasi Kabupaten Bungo sesuai dengan Standar Akuntansi Pemerintahan (Peraturan Pemerintah Nomor 24 Tahun 2005). Hasil penelitian menunjukkan bahwa, Akuntansi Aset Tetap pada Dinas Tenaga Kerja dan Transmigrasi Kabupaten Bungo belum sesuai dengan Standar Akuntansi Pemerintahan (Peraturan Pemerintah Nomor 24 Tahun 2005). Terdapat persamaan dalam penelitian ini yaitu Menganalisis perlakuan Akuntansi Aset Tetap, Sedangkan perbedaanya Peneliti menggunakan Peraturan Pemerintah No. 71 Tahun 2010.

Risca Kurniawati (2013), Analisis Perlakuan Akuntansi Aset Tetap Pada Kementrian Pekerjaan Umum. Penelitian dilakukan dengan tujuan Untuk Menganalisis apakah perlakuan akuntansi aset pemerintah dan prisip umum. Hasil penelitian menunjukkan bahwa Semua fungsi akuntansi dalam bidang apapun sama, namun pada pemerintahan terdapat fungsi-fungsi khusus yang membedakan. Terdapat persamaan dalam penelitian ini yaitu Menganalisis perlakuan akuntansi aset tetap pada dinas pekerjaan umum, Sedangkan perbedaanya Peneliti meneliti Perlakuan Akuntansi Aset Tetap berdasarkan PP No.71 Tahun 2010.

Auliana (2014), Analisis Akuntansi Aset Tetap Pada Badan Penanggulangan Bencana Daerah Kota Tanjung Pinang Berdasar Pernyataan Standar Akuntansi Pemerintahan No. 07. Penelitian dilakukan dengan tujuan Untuk mengetahui apakah perlakuan akuntansi aset tetap pada BPD Kota Tanjung Pinang sudah sesuai dengan PSAP No. 07. Hasil penelitian menunjukkan bahwa Akuntansi aset tetap yang diterapkan oleh BPBD Kota Tanjungpinang untuk pendefinisian, pengakuan serta pengukuran asset tetap telah sesuai dengan PSAP No. 07, kecuali pada pengungkapan. Terdapat persamaan dalam penelitian ini yaituMenganalisis Perlakuan Akuntansi Aset Tetap berdasarkan PSAP N0. 07, , Sedangkan perbedaanya Objek yang diteliti pada Dinas Pekerjaan Umum Provinsi Sulawesi Utara.

\section{METODE PENELITIAN}

Penelitian ini termasuk pada jenis penelitian deskriptif yang tujuannya untuk menyajikan gambaran lengkap mengenai setting sosial atau hubungan antara fenomena yang diuji. Jenis penelitian dilakukan langsung ke sumber data, pengumpulan data menggunakan instrument penelitian.

Data dan informasi yang dikumpulkan akan dianalisis dengan menggunakan metode komparatif yaitu dengan cara membandingkan kesesuaian antara perlakuan akuntansi dalam Satuan Kerja Perangkat Daerah (SKPD) dan Peraturan Pemerintah tentang Standar Akuntansi Pemerintahan. Penekanan metode analisis ini yakni pada bagaimana perlakuan akuntansi aset tetap pada Dinas Pekerjaan Umum Provinsi Sulawesi Utara apakah telah sesuai dengan Peraturan Pemerintah No.71 tentang Standar Akuntansi Pemerintahan. 


\section{Hasil Penelitian}

\section{HASIL PENELITIAN DAN PEMBAHASAN}

Kebijakan akuntansi yang berlaku di Dinas Pekerjaan Umum Prov. Sulawesi Utara merujuk pada Peraturan Pemerintah No.24 Tahhun 2005 dengan basis akuntansi yang digunakan yakni Cash Toward Accrual (CTA). Kebijakan akuntansi ini meliputi seluruh pos-pos utama dari laporan mengenai posisi aset dan laporan perubahan dalam posisi aset, yang diakibatkan oleh aktivitas yang dilakukan di dalam pelayanan kepada masyarakat. Periode akuntansi Dinas Pekerjaan Umum untuk penyajian laporan keuangan adalah satu tahun menurut tahun takwim, yaitu 1 Januari s/d 31 Desember.

Dinas Pekerjaan Umum Prov. Sulawesi Utara merupakan salah satu Satuan Kerja Perangkat Daerah (SKPD) yang ada di Kota Manado yang bertugas untuk membantu Pemerintah dan Masyarakat dalam penyediaan prasarana dan sarana berdasarkan Peraturan Pemerintah No.24 Tahun 2005. Pada SKPD ini aset tetap memiliki pengertian yang sama dengan pengertian aset tetap dalam Pernyataan Standar Akuntansi Pemerintahan, yaitu Aset berwujud yang mempunyai masa manfaat lebih dari 12 (dua belas) bulan untuk digunakan, atau dimaksudkan untuk digunakan, untuk aset tetap dalam bentuk peralatan dan mesin dapat diakui sebagai aset tetap apabila biaya perolehan aset tetap tersebut lebih dari Rp. 300.000 dan untuk aset tetap dalam bentuk jalan dapat diakui sebagai aset tetap apabila biaya perolehan aset tetap tersebut lebih dari Rp. 10.000.000.

Penulis telah melakukan wawancara dan pengolahan data yang berkaitan dengan Perlakuan Akuntansi Aset Tetap pada Dinas Pekerjaan Umum Provinsi Sulawesi Utara. Wawancara yang dilakukan menghasilkan data yang dapat dibandingkan dengan Peraturan Pemerintah Nomor 71 Tahun 2010, Pernyataan Nomor 7 tetang Aset Tetap.

Penjelasan mengenai penelitian ini diuraikan pula dengan beberapa tabel perbandingan sesuai atau tidaknya perlakuan Akuntansi Pemerintahan tentang Aset Tetap pada Dinas Pekerjaan Umum Provinsi Sulawesi Utara dengan Peraturan Pemerintah Nomor 71 Tahun 2010, Pernyataan Nomor 7 tentang Aset Tetap.

\section{PEMBAHASAN}

Tabel 1

Pengakuan Aset Tetap oleh Dinas Pekerjaan Umum Prov. Sulawesi Utara dengan PSAP No. 07

\begin{tabular}{|c|c|c|}
\hline PSAP Nomor 07 & $\begin{array}{c}\text { Dinas Pekerjaan Umum Prov. Sulawesi } \\
\text { Utara }\end{array}$ & Keterangan \\
\hline $\begin{array}{l}\text { a. Masa manfaat lebih dari } 12 \\
\text { (dua belas) bulan. }\end{array}$ & $\begin{array}{l}\text { a. Suatu aset akan diakui sebagai aset tetap } \\
\text { apabila aset tersebut memiliki masa } \\
\text { manfaat lebih dari dua belas bulan. }\end{array}$ & Sesuai \\
\hline $\begin{array}{l}\text { b. Biaya perolehan dapat diukur } \\
\text { secara andal. }\end{array}$ & $\begin{array}{l}\text { b. Aset tetap diakui menggunakan biaya } \\
\text { perolehan yang dapat diukur secara andal. }\end{array}$ & Sesuai \\
\hline $\begin{array}{llr}\text { c. Tidak dimaksudkan untuk } \\
\text { dijual dalam operasi normal } \\
\text { entitas. }\end{array}$ & $\begin{array}{l}\text { c. Maksud pengadaan aset tetap bukan untuk } \\
\text { dijual melainkan suatu aset tetap diperoleh } \\
\text { dengan maksud untuk digunakan dalam } \\
\text { menunjang kegiatan operasional entititas. }\end{array}$ & Sesuai \\
\hline $\begin{array}{llrr}\text { d. } & \begin{array}{l}\text { Diperoleh } \\
\text { dengan } \\
\text { digunakan. }\end{array} & \begin{array}{c}\text { atau } \\
\text { maksud }\end{array} & \begin{array}{r}\text { dibangun } \\
\text { untuk }\end{array} \\
\end{array}$ & $\begin{array}{l}\text { d. Pengadaan suatu aset adalah untuk } \\
\text { digunakan dalam aktifitas entitas. }\end{array}$ & Sesuai \\
\hline $\begin{array}{l}\text { e. Pengakuan aset tetap akan } \\
\text { sangat andal apabila aset tetap } \\
\text { telah diterima atau diserahkan } \\
\text { hak kepemilikannya pada saat } \\
\text { penguasaannya berpindah. }\end{array}$ & $\begin{array}{l}\text { e. Aset tetap akan diakui pada saat transaksi } \\
\text { atas aset tetap tersebut terjadi. Contohnya } \\
\text { jika transaksi terjadi tanggal } 8 \text { Juni maka } \\
\text { aset tetap tersebut diakui pada tanggal } 8 \\
\text { Juni. }\end{array}$ & Sesuai \\
\hline
\end{tabular}

(Sumber : Data Olahan, 2015)

Dari tabel 1 diatas terlihat bahwa perlakuan akuntansi aset tetap atas pengakuan aset tetap oleh Dinas Pekerjaan Umum Prov. Sulawesi Utara telah sesuai dengan peraturan pemerintah yang berlaku yaitu Peraturan Pemerintah No. 71 Tahun 2010 pernyataan No. 07 tentang akuntansi aset tetap. Mulai dari masa manfaat asset yang harus lebih dari 12 bulan hingga saat yang tepat untuk aset diakui sebagai aset tetap. Menurut penulis Dinas Pekerjaan Umum Prov. Sulawesi Utara telah mengikuti peraturan yang berlaku. 
Tabel 2

Pengukuran Aset Tetap oleh Dinas Pekerjaan Umum Prov. Sulawesi Utara

dengan PSAP No.07

\begin{tabular}{|c|c|c|}
\hline PSAP No. 07 & $\begin{array}{c}\text { Dinas Pekerjaan Umum Prov. Sulawesi } \\
\text { Utara }\end{array}$ & Keterangan \\
\hline $\begin{array}{l}\text { a. Aset tetap dinilai dengan biaya } \\
\text { perolehan. Apabila penilaian aset } \\
\text { tetap dengan biaya perolehan } \\
\text { tidak memungkinkan maka nilai } \\
\text { aset tetap didasarkan pada nilai } \\
\text { wajar pada saat perolehan. }\end{array}$ & $\begin{array}{l}\text { a. Penilaian atas suatu aset tetap pada Dinas } \\
\text { Pekerjaan Umum Prov. Sulawesi Utara } \\
\text { adalah dengan menggunakan biaya } \\
\text { perolehan yakni dinilai berdasarkan } \\
\text { seluruh biaya yang dikeluarkan hingga aset } \\
\text { tetap tersebut siap untuk digunakan. }\end{array}$ & Sesuai \\
\hline $\begin{array}{l}\text { b. Biaya perolehan suatu aset tetap } \\
\text { terdiri dari harga belinya } \\
\text { termasuk bea impor dan setiap } \\
\text { biaya yang dapat diatribusikan } \\
\text { secara langsung }\end{array}$ & $\begin{array}{l}\text { b. Biaya perolehan suatu aset tetap pada } \\
\text { Dinas Pekerjaan Umum Prov. Sulawesi } \\
\text { Utara terdiri harga beli aset tetap tersebut, } \\
\text { biaya angkut dan biaya instalasi yang } \\
\text { dikeluarkan untuk aset tetap tersebut. }\end{array}$ & Sesuai \\
\hline
\end{tabular}

(Sumber : Data Olahan, 2015)

Berdasarkan tabel 2 diatas terlihat bahwa perlakuan akuntansi aset tetap tentang pengukuran aset tetap oleh Dinas Pekerjaan Umum Prov. Sulawesi Utara telah sesuai dengan peraturan pemerintah yang berlaku yaitu Peraturan Pemerintah No 71 tahun 2010 pernyataan No. 07 tentang akuntansi aset tetap. Menurut penulis pengukuran Dinas Pekerjaan Umum Prov. Sulawesi Utara dinilai dengan biaya perolehan.

Tabel 3

Pengeluaran Setelah Perolehan oleh Dinas Pekerjaan Umum Prov. Sulawesi Utara dengan PSAP No. 07

\begin{tabular}{|c|c|c|}
\hline PSAP No. 07 & $\begin{array}{c}\text { Dinas Pekerjaan Umum Prov. Sulawesi } \\
\text { Utara }\end{array}$ & Keterangan \\
\hline $\begin{array}{l}\text { Pengeluaran setelah perolehan awal } \\
\text { suatu aset tetap yang } \\
\text { memperpanjang masa manfaat atau } \\
\text { yang kemungkinan besar memberi } \\
\text { manfaat ekonomik di masa yang } \\
\text { akan datang dalam bentuk kapasitas, } \\
\text { mutu produksi atau peningkatan } \\
\text { standar kinerja, harus ditambahkan } \\
\text { pada nilai tercatat aset yang } \\
\text { bersangkutan. }\end{array}$ & $\begin{array}{l}\text { Pengeluaran untuk perbaikan atau perawatan } \\
\text { aset tetap yang memperpanjang masa manfaat } \\
\text { dan akan memberi manfaat dalam periode } \\
\text { berjalan dan dimasa akan datang dalam bentuk } \\
\text { kapasitas, mutu produksi, atau peningkatan } \\
\text { standar kinerja, dan ditambahkan pada nilai } \\
\text { tercatat aset yang bersangkutan. Untuk contoh } \\
\text { jurnal atas pengeluaran setelah perolehan aset } \\
\text { tetap dapat dilihat pada halaman } 44 \text {. }\end{array}$ & Sesuai \\
\hline
\end{tabular}

(Sumber : Data Olahan, 2015)

Pada tabel 3 di atas terlihat bahwa pengeluaran untuk perbaikan suatu aset tetap pada Dinas Pekerjaan Umum Prov. Sulawesi Utara tidak dikapitalisasi pada aset tetap yang bersangkutan melainkan diakui sebagai beban dan langsung dibebankan sebagai beban dalam laporan laba rugi. Hal ini dianggap sesuai dengan Peraturan Pemerintah No. 71 Tahun 2010 pernyataan No. 07 tentang akuntansi aset tetap.

Tabel 4

Penyusutan oleh Dinas Pekerjaan Umum Prov. Sulawesi Utara dengan PSAP No 07

\begin{tabular}{|l|l|c|}
\hline \multicolumn{1}{|c|}{ PSAP No. 07 } & \multicolumn{1}{|c|}{$\begin{array}{c}\text { Dinas Pekerjaan Umum Prov. } \\
\text { Sulawesi Utara }\end{array}$} & Keterangan \\
\hline $\begin{array}{l}\text { Nilai penyusutan untuk masing- } \\
\text { masing periode diakui sebagai } \\
\text { pengurang nilai tercatat aset tetap dan } \\
\text { diinvestasikan dalam aset tetap. }\end{array}$ & $\begin{array}{l}\text { Pada saat peneliti melakukan penelitian } \\
\text { ini, Dinas Pekerjaan Umum Prov. } \\
\text { Sulawesi Utara belum pernah melakukan } \\
\text { penyusutan atas nilai aset tetap yang } \\
\text { dimiliki. Hal ini dikarenakan belum } \\
\text { adanya petunjuk teknis tentang } \\
\text { penyusutan aset tetap yang dikeluarkan } \\
\text { oleh pihak yang berwenang. }\end{array}$ & \\
\hline
\end{tabular}

(Sumber : Data Olahan, 2015) 
Berdasarkan tabel 4 diatas terlihat bahwa hingga saat peneliti melakukan penelitian ini, Dinas Pekerjaan Umum Prov. Sulawesi Utara belum pernah melakukan penyusutan hal ini dikarenakan belum adanya petunjuk teknis tentang penyustan aset tetap yang dikeluarkan oleh pihak yang berwenang. Hal ini dianggap belum sesuai dengan peraturan pemerintah yang berlaku yaitu Peraturan Pemerintah No. 71 Tahun 2010 pernyataan No. 07 tentang akuntansi aset tetap karena penyusutan sangatlah penting untuk mengetahui nilai atas suatu aset yang dimiliki.

Tabel 5

Penghentian dan Pelepasan oleh Dinas Pekerjaan Umum Prov. Sulawesi Utara dengan PSAP No. 07

\begin{tabular}{|c|c|c|}
\hline PSAP No. 07 & $\begin{array}{c}\text { Dinas Pekerjaan Umum Prov. Sulawesi } \\
\text { Utara }\end{array}$ & Keterangan \\
\hline $\begin{array}{l}\text { a. Suatu aset tetap dieliminasi dari } \\
\text { neraca ketika dilepaskan atau bila } \\
\text { aset secara permanen dihentikan } \\
\text { penggunaannya dan tidak ada } \\
\text { manfaat ekonomik masa yang } \\
\text { akang datang. }\end{array}$ & $\begin{array}{l}\text { a. Suatu aset yang dianggap sudah tidak } \\
\text { lagi memiliki manfaat akan } \\
\text { dieliminasi dari neraca dan dihentikan } \\
\text { penggunaannya. }\end{array}$ & Sesuai \\
\hline $\begin{array}{l}\text { b. Aset tetap yang dihentikan dari } \\
\text { penggunaan aktif pemerintah tidak } \\
\text { memenuhi definisi aset tetap dan } \\
\text { harus dipindahkan ke pos aset } \\
\text { lainnya. }\end{array}$ & $\begin{array}{l}\text { b. Aset tetap didefinisikan merupakan } \\
\text { aset yang memiliki masa manfaat } \\
\text { lebih dari dua belas bulan namun jika } \\
\text { aset tetap tidak lagi memenuhi definisi } \\
\text { yang ada maka aset tersebut akan } \\
\text { dihentikan dari penggunaannya dan } \\
\text { dipindahkan ke pos aset lain-lain. }\end{array}$ & Sesuai \\
\hline
\end{tabular}

(Sumber : Data Olahan, 2015)

Pada tabel 5 diatas terlihat bahwa perlakuan akuntansi aset tetap tentang penghentian dan pelepasan yang diterapkan pada Dinas Pekerjaan Umum Prov. Sulawesi Utara telah sesuai dengan peraturan pemerintah yang berlaku yaitu Peraturan Pemerintah No. 71 tahun 2010 pernyataan No. 07. Maka Dinas Pekerjaan Umum Prov. Sulawesi Utara akan segera memindahkan aset tetap yang dianggap tidak lagi memenuhi definisi aset tetap ke pos aset lain-lain.

\section{Tabel 6}

Pengungkapan Aset Tetap oleh Dinas Pekerjaan Umum Prov. Sulawesi Utara dengan PSAP No. 07

\begin{tabular}{|c|c|c|}
\hline PSAP No. 07 & $\begin{array}{c}\text { Dinas Pekerjaan Umum Prov. Sulawesi } \\
\text { Utara }\end{array}$ & Keterangan \\
\hline $\begin{array}{llr}\text { a. } & \text { Laporan keuangan } & \text { harus } \\
\text { mengungkapkan } & \text { dasar } \\
\text { penilaian yang digunakan untuk } & \text { menentukan nilai tercatat. }\end{array}$ & $\begin{array}{l}\text { a. Dinas Pekerjaan Umum Prov. Sulawesi } \\
\text { Utara mengungkapkan dasar penilaian } \\
\text { yang digunakan untuk menentukan nilai } \\
\text { tercatat dalam laporan keuangan, yaitu } \\
\text { aset tetap dinilai dengan biaya } \\
\text { perolehan. }\end{array}$ & Sesuai \\
\hline $\begin{array}{l}\text { b. Ssetiap jenis aset seperti tanah, } \\
\text { gedung dan bangunan, } \\
\text { peralatan dan mesin dan lain } \\
\text { sebagainya harus dinyatakan } \\
\text { dalam neraca secara terpisah } \\
\text { atau terperinci dalam catatan } \\
\text { atas laporan keuangan. }\end{array}$ & $\begin{array}{l}\text { b. Semua aset tetap yang dimiliki oleh } \\
\text { Dinas Pekerjaan Umum Prov. Sulawesi } \\
\text { Utara seperti tanah, peralatan dan mesin, } \\
\text { gedung dan bangunan, jalan irigasi dan } \\
\text { jaringan dan aset lain-lain dinyatakan } \\
\text { secarah terpisah dalam neraca dan } \\
\text { terperinci dalam Catatan atas Laporan } \\
\text { Keuangan entitas. }\end{array}$ & Sesuai \\
\hline $\begin{array}{l}\text { c. Rekonsiliasi jumlah tercatat } \\
\text { pada awal dan akhir periode } \\
\text { yang menunjukkan } \\
\text { penambahan, pelepasan, } \\
\text { akumulasi penyusutan dan } \\
\text { perubahan nilai jika ada mutasi } \\
\text { aset tetap lainnya. }\end{array}$ & $\begin{array}{llr}\text { c. laporan keuangan Dinas } & \text { Pekerjaan } \\
\text { Umum Prov. Sulawesi } & \text { Utara } \\
\text { mengungkapkan rekonsiliasi jumlah } \\
\text { tercatat yang menunjukkan pelepasan } \\
\text { dan mutasi aset tetap lainnya selama } \\
\text { periode tahun berjalan. }\end{array}$ & Sesuai \\
\hline
\end{tabular}

(Sumber : Data Olahan, 2015) 
Berdasarkan tabel 6 diatas terlihat bahwa perlakuan akuntansi aset tetap atas pengungkapan aset tetap yang diterapkan pada Dinas Pekerjaan Umum Prov. Sulawesi Utara telah sesuai dengan peraturan pemerintah yang berlaku yaitu Peraturan Pemerintah No. 71 tahun 2010 pernyataan N0. 07. Maka Dinas Pekerjaan Umum Prov. Sulawesi Utara mengungkapkan dasar penilaian yang digunakan untuk menilai suatu aset selain itu setiap jenis aset yang dimiliki juga disajikan secara terpisah dalam neraca dan terperinci dalam Catatan atas Laporan Keuangan.

\section{KESIMPULAN}

Berdasarkan hasil penelitian dan pembahasan yang telah dilakukan dalam menganalisis perlakuan akuntansi aset tetap pada Dinas Pekerjaan Umum (PU) Provinsi Sulawesi Utara maka dapat ditarik kesimpulan sebagai berikut :

1. Pengakuan aset tetap pada Dinas Pekerjaan Umum (PU) Provinsi Sulawesi Utara telah sesuai dengan SAP No. 07.

2. Pengukuran/Penilaian aset tetap pada Dinas Pekerjaan Umum (PU) Provinsi Sulawesi Utara telah sesuai dengan SAP No. 07.

3. Dalam hal Pengeluaran Setelah Perolehan Dinas Pekerjaan Umum (PU) Provinsi Sulawesi Utara sudah sesuai dengan SAP No. 07.

4. Dinas Pekerjaan Umum (PU) Provinsi Sulawesi Utara belum pernah melakukan penyusutan atas aset tetap dikarenakan belum adanya prosedur petunjuk teknis penyusutan aset tetap.

5. Penghentian dan Pelepasan aset tetap Dinas Pekerjaan Umum (PU) Provinsi Sulawesi Utara sudah sesuai dengan SAP No. 07.

6. Dalam hal Pengungkapan Aset Tetap dalam Laporan Keuangan, Dinas Pekerjaan Umum (PU) Provinsi Sulawesi Utara telah menyajikan informasi yang berkaitan dengan aset tetap secara terperinci.

\section{DAFTAR PUSTAKA}

Andriyani Lysa 2008. Analisis Perlakuan Akuntansi Aset Daerah Dalam Penyusunan Neraca Pada Pemerintah Kabupaten Jember. Universitas Brawijaya. Malang.

Auliana. 2014. Analisis Akuntansi Aset Tetap Pada Badan Penanggulangan Bencana Daerah Kota Tanjung Pinang Berdasar Pernyataan Standar Akuntansi Pemerintahan No. 07. Skripsi (tidak dipublikasikan). Fakultas Ekonomi Universitas Maritim Raja Ali Haji Tanjungpinang.

Bahtiar Arif, Muchlis, Iskandar. 2010. Akuntansi Pemerintahan. Salemba Empat. Jakarta.

BPKP. (2002). Modul Pelatihan Dasar-Dasar Akuntansi 1. Jakarta : Badan Pengawasan Keuangan dan Pembangunan.

Halim, Abdul. 2010. Akuntansi Sektor Publik. Salemba Empat. Jakarta.

Indriantoro, Nur dan Bambang Supomo, 2011, Metodologi Penelitian Bisnis dan Akuntansi Manajemen. BPFE. Yogyakarta

Ismail. 2010. Akuntansi Bank. PT Kencana, Surabaya.

Kustadi, Arinta. 2009. Pengantar Akuntansi Pemerintahan. Citra Aditya Bakti. Bandung.

Lysa Dwi Andriyai (2008). Analisis Perlakuan Akuntansi Aset Daerah dalam penyusunan Neraca Pada Pemerntah Kabupaten Jember. Fakultas Ekonomi Universitas Brawijaya

Misliana (2013). Analisis Akuntansi Aset Tetap Pada Pemerintah Kota Tanjungpinang. Fakultas

Ekonomi Universitas Maritim Raja Ali Haji Tanjungpinang

Nordiawan,Deddi,Putra,Sondi I. Rahmawati,Maulida.2012.Akuntansi Sektor Publik. Salemba Empat. Jakarta.

Peraturan Pemerintah Republik Indonesia Nomor 71 Tahun 2010 tentang Akuntansi.

Peraturan Pemerintah Republik Indonesia Nomor 71 Tahun 2010 tentang Standar Akuntansi Pemerintahan.

Peraturan pemerintah Republik Indonesia Nomor 71 Tahun 2010 pernyataan No. 7 tentang Akuntansi Aset Tetap.

Peraturan Pemerintah Republik Indonesia Nomor 24 Tahun 2005 tentang Akuntansi Aset Tetap

Peraturan Pemerintah Republik Indonesia Nomor 56 Tahun 2005 Tentang Sistem Informasi Keuangan Daerah 
Peraturan Walikota Manado Nomor 34 tahun 2014 Tentang Kebijakan Akuntansi Pemerintah Daerah Kota Manado

Reevrisond, Baswir. 2009. Akuntansi Pemerintahan Indonesia. BPFE. Yogyakarta.

Septiana Tri. 2011. Analisis Akuntansi Aset Tetap Pada Dinas Tenaga Kerja dan Transmigrasi Kabupaten Bungon Berdasarkan Standar Akuntansi Pemerintahan(PP 24 Tahun 2005).Skripsi (tidak dipublikasikan). Fakultas Ekonomi Universitas Andalas. Padang.

Soemarso, S.R. 2010. Pengantar Akuntansi. Edisi Kelima. Salemba Empat. Jakarta.

Suwardjono. 2013. Akuntansi Pengantar. Edisi Keenam. BPFE, Yogyakarta.

Undang-undang Nomor 25 Tahun 2004 tentang Sistem Perencanaan Pembangunan Nasional. 